\title{
EFEKTIVITAS IMUNOMODULATOR EKSTRAK DAUN MACANG (Mangifera Foetida L.) TERHADAP SEL MAKROFAG TIKUS PUTIH (Rattus norvegicus)
}

\author{
Sri Nur Kholifah, Fitmawati \\ Jurusan Biologi, Fakultas Matematika dan Ilmu Pengetahuan Alam, \\ Universitas Riau, Kampus Binawidya \\ E-mail: srnrkholifah@gmail.com
}

DOI: dx.doi.org/10.26418/jpmipa.v11i1.32763

\begin{abstract}
Macang (Mangifera foetida L.) has potential as an effect herbal medicinal plant with antioxidant content, namely mangiferin. The aim of this study is to prove empirically study that macang has an immunomodulatory effect through preclinical testing. This study use white mice (Rattus norvegicus) as experimental animals and Staphylococcus aureus as test bacteria. Rats were give leaf extracts of 3 varieties of orally for 7 days using 3 prescribe doses in ppm. On the $8^{\text {th }}$ day, each rats was induce by an intraperitoneal section with $0,5 \mathrm{ml}$ of the bacterial suspension tested. Observation of peritoneal fluid through smear preparations includes 2 parameters, phagocytosis activity and capacity. The result showed that the immunomodulatory effects on batu varieties were effective at dose $2(10 \mathrm{ppm}=0,01 \mathrm{mg} / \mathrm{g})$, limus varieties and manis varieties were effective at dose $1(1 \mathrm{ppm}=0,001 \mathrm{mg} / \mathrm{g})$. According to this research, it was concluded that leaf extracts of three varieties macang could be used as immunomodulators.
\end{abstract}

Keywords: macrophage phagocytosis, immunomodulatory, mangifera foetida

\begin{abstract}
Abstrak
Macang (Mangifera foetida L.) mempunyai potensi sebagai tumbuhan obat herbal dengan kandungan antioksidan yaitu mangiferin. Tujuan penelitian ini adalah membuktikan efek imunomodulator pada tiga varietas macang (batu, limus dan manis) melalui uji praklinik. Penelitian ini menggunakan tikus putih (Rattus norvegicus) sebagai hewan uji dan Staphylococcus aureus sebagai bakteri uji. Tikus diberi ekstrak daun tiga varietas macang secara oral selama tujuh hari menggunakan tiga serial dosis dalam satuan ppm. Pada hari ke-8, setiap tikus putih diinduksi bagian intraperitoneal dengan 0,5 ml suspensi bakteri uji. Pengamatan cairan peritoneal melalui preparat apusan meliputi 2 parameter yaitu aktivitas dan kapasitas fagositosis. Hasil penelitian menunjukkan bahwa efek imunomodulator pada varietas batu
\end{abstract}

$\begin{array}{ll}\text { Received } & : 22 / 04 / 2019 \\ \text { Revised } & : 27 / 12 / 2019 \\ \text { Accepted } & : 06 / 01 / 2020\end{array}$


efektif pada dosis $2(10 \mathrm{ppm}=0,01 \mathrm{mg} / \mathrm{g})$, varietas limus dan manis efektif pada dosis 1 (10 ppm=0,001mg/g). Disimpulkan bahwa daun macang (Mangifera foetida) berpotensi digunakan sebagai imunomodulator.

Kata kunci : fagositosis makrofag, imunomodulator, mangifera foetida

Penyakit degeneratif disebabkan oleh menurunnya fungsi sel pada tubuh. Penyakit ini terus meningkat akibat perubahan gaya hidup masyarakat saat ini pola makan, serta kurangnya aktivitas fisik. Hal tersebut dapat menurunkan sistem kekebalan didalam tubuh. Menurunnya sistem imun menyebabkan masuknya radikal bebas yang berdampak pada kerusakan sel, sehingga menimbulkan penyakit (Limyati \& Essay, 2003). Antioksidan merupakan suatu senyawa yang mampu menekan dan mencegah terjadinya radikal bebas dalam proses oksidasi lipid (Ahmad et al., 2012). Sebagai agen imunostimulativ, antioksidan menjaga ketahanan sistem imun dengan menguatkan kembali keseimbangan tubuh. Tumbuhan berpotensi sebagai sumber antioksidan dan beberapa jenis memiliki kandungan antioksidan setara dengan vitamin $\mathrm{C}$ (asam askorbat), salah satunya adalah mangga.

Macang merupakan salah satu mangga jenis liar dalam anggota genus Mangifera yang. Jenis mangga liar memiliki ciri buah beraroma khas, serta memiliki rasa buah yang masam. Rasa masam pada buah ini menjadi petunjuk adanya senyawa potensial obat. Berdasarkan penelitian identifikasi senyawa oleh Purwaningsih, et al. (2011) menunjukkan bahwa infusa daun macang mengandung metabolit sekunder berupa flavonoid, saponin, tanin dan xantonoid berupa mangiferin yang dapat bersifat sebagai antioksidan.

Macang memiliki potensi sebagai tumbuhan obat herbal imunomodulator dengan kandungan antioksidan yaitu mangiferin. Kandungan mangiferin pada macang lebih tinggi dibandingkan pada Mangifera indica, yaitu sebesar 2,56\% (Purwaningsih, et al., 2011). Hasil penelitian Siswanty et al. (2017) kandungan antioksidan ekstrak metanol daun macang diperoleh nilai $\mathrm{IC}_{50} 9,653$ ppm. Antioksidan dikatakan sangat kuat jika nilai $\mathrm{IC}_{50}$ kecil dari 50 ppm. Semakin kecil nilai $\mathrm{IC}_{50}$, maka semakin tinggi aktivitas antioksidan

Penelitian tentang imunomodulator pada mangga sudah pernah dilaporkan, dan terfokus pada mangga budidadaya, diantaranya Mangifera indica (Savant, et al., 2014; Grace, et al., 2013; Wei, et al., 2011). Selain itu, juga pada jenis liar endemik Kalimantan oleh Rahim, et al. (2017) pada Mangifera casturi dan tiga jenis mangga liar (Mangifera magnifica, Mangga Hutan dan Mangga Bukit Suligi) oleh Fitmawati, et al. (2018). Namun, belum ada informasi pembuktian empiris yang mendukung bahwa macang mempunyai efek imunomodulator. Oleh karena itu, perlu dilakukan uji praklinis terhadap efektivitas ekstrak daun macang sebagai imunomodulator. Tujuan dari penelitian ini adalah membuktikan efek imunomodulator ekstrak daun tiga varietas macang dengan mengetahui respon aktivitas dan kapasitas fagositosis sel makrofag cairan peritoneal tikus putih setelah distimulasi ekstrak terhadap infeksi bakteri Staphylococcus aureus.

\section{METODE}

Persiapan Hewan Uji 
Tikus putih jantan galur Wistar berumur tiga bulan dengan berat badan 220-260 g ditempatkan di kandang hewan. Selama pemeliharaan dan perlakuan, hewan uji diberi minum akuades dan pakan standar secara ad libitum.

\section{Pembuatan Ekstrak Macang}

Sampel serbuk daun macang dimaserasi dengan pelarut metanol, kemudian disaring dengan kertas saring. Filtrat diuapkan atau dipekatkan dengan rotary evaporator sampai terbentuk ekstrak yang kental.

\section{Penetapan Dosis Hewan Uji}

Pembuatan larutan stok yaitu 100 mg ekstrak kental dalam $10 \mathrm{ml}$ akuades. Penggunaan dosis ekstrak daun macang menggunakan konsentrasi 1 ppm $(0,001$ $\mathrm{mg} / \mathrm{g}), 10 \mathrm{ppm}(0,01 \mathrm{mg} / \mathrm{g})$ dan $100 \mathrm{ppm}$ $(0,1 \mathrm{mg} / \mathrm{g})$.

\section{Persiapan Medium}

Medium dibuat dengan mensuspensikan $21 \mathrm{~g}$ media Mueller Hinton Broth (MHB) dalam satu liter akuades, lalu disterilisasi menggunakan autoklaf $121^{\circ} \mathrm{C}$ selama 15 menit.

\section{Bakteri Uji}

Bakteri dari biakan murni ditumbuhkan dalam medium MHB cair sebanyak $10 \mathrm{ml}$ lalu diinkubasi menggunakan shaker incubator pada suhu $37^{\circ} \mathrm{C}$ dengan kecepatan rotasi 150 rpm. Selanjutnya dilakukan pengenceran menggunakan larutan garam fisiologis $(\mathrm{NaCl})$ 0,85\% untuk mendapatkan jumlah bakteri $10^{8} \mathrm{cfu} / \mathrm{ml}$ (Yulinery dan Nurhidayat, 2012).

\section{Pemberian Ekstrak Macang per Oral}

Hewan uji dikelompokkan secara acak dengan dibagi menjadi 12 kelompok dan masing-masing kelompok terdiri dari tiga ekor tikus. Pemberian ekstrak dilakukan per oral selama satu minggu sesuai dengan dosis yang sudah ditetapkan.

\section{Uji Fagositosis}

Pada hari kedelapan, setiap tikus putih diinduksi bagian intraperitoneal dengan $0,5 \mathrm{ml}$ suspensi $S$. aureus dan dibiarkan selama satu jam. Setelah itu, tikus dibedah bagian perut. Kemudian cairan peritoneal diambil, dipulas pada gelas objek dan difiksasi dengan metanol selama lima menit, diwarnai dengan pewarnaan giemsa, didiamkan selama 20 menit, dibilas dengan air mengalir. Setelah sediaan kering, dilihat dibawah mikroskop menggunakan minyak imersi dengan perbesaran 1000x, dihitung aktivitas dan kapasitas fagositosis makrofag (Fitmawati, et al., 2017).

\section{Analisis Data}

Penentuan perbedaan pengaruh ekstrak daun tiga varietas macang dengan variasi dosis terhadap aktivitas dan kapasitas fagositosis sel makrofag digunakan uji ANOVA (analysis of variance) satu arah (one way), dengan uji lanjut Duncant Multiple Range Test (DMRT) dengan program SPSS for Windows 23.

\section{HASIL DAN PEMBAHASAN}

Pengujian efektivitas imunomodulator ekstrak daun macang dilakukan melalui pengamatan dan perhitungan terhadap aktivitas dan kapasitas makrofag (sel darah putih) pada gambaran preparat apusan cairan peritoneal (Gambar 1 sampai dengan Gambar 4). Makrofag didalam tubuh hewan uji berperan dalam fagositosis patogen-patogen di dalam tubuh. Patogen yang diinfeksikan melalui intraperitoneal tikus putih adalah bakteri S. aureus. 


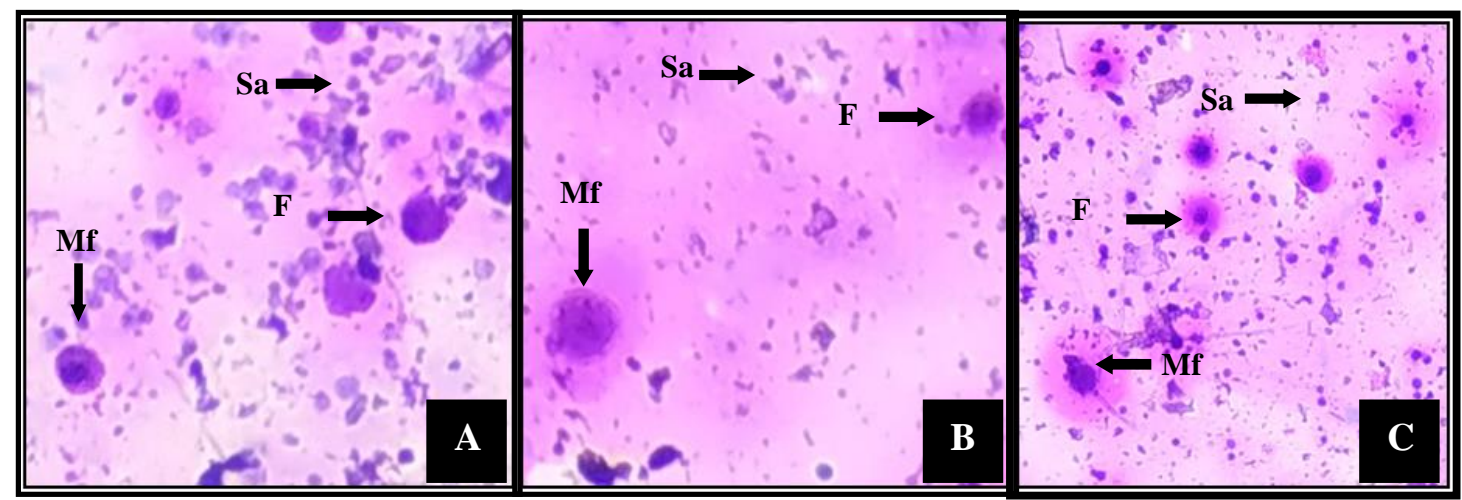

Gambar 1. Gambaran apusan cairan peritoneal. Keterangan A: Kontrol positif (stimuno), B: Kontrol nol (aquades), C: Kontrol negatif (CMC Na 1\%). F: fagositosis, M: makrofag, S: bakteri S. aureus

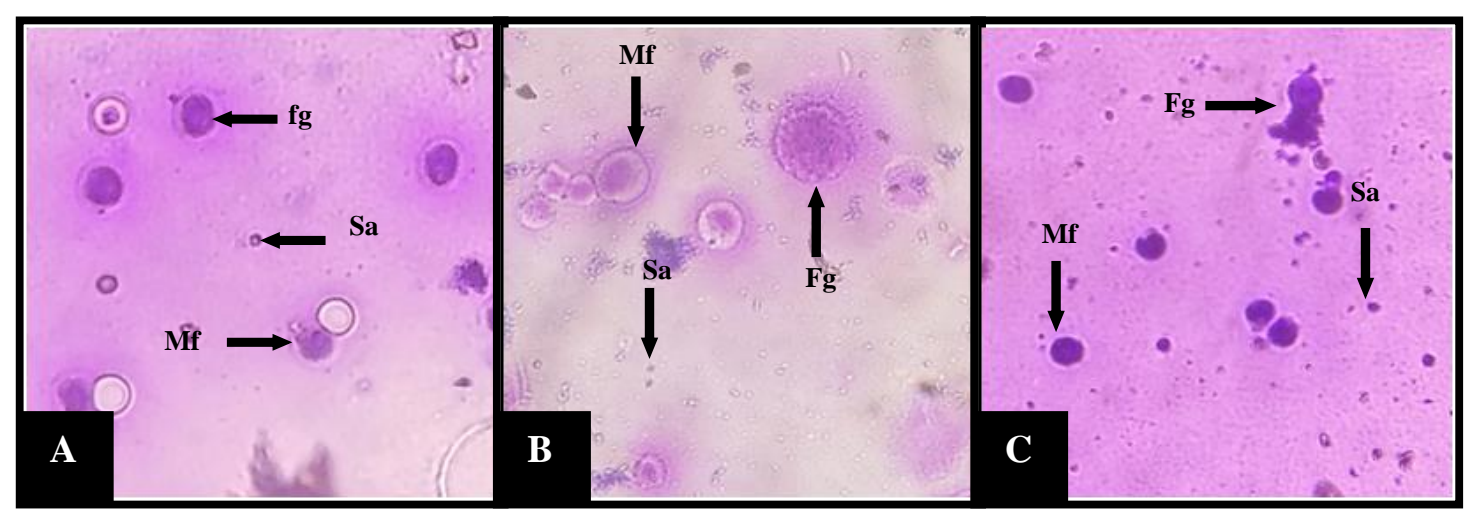

Gambar 2. Gambaran apusan cairan peritoneal ekstrak daun macang varietas batu. Keterangan A: Dosis 1, B: Dosis 2, C: Dosis 3. F: Fagositosis, M: makrofag, S: bakteri S. aureus

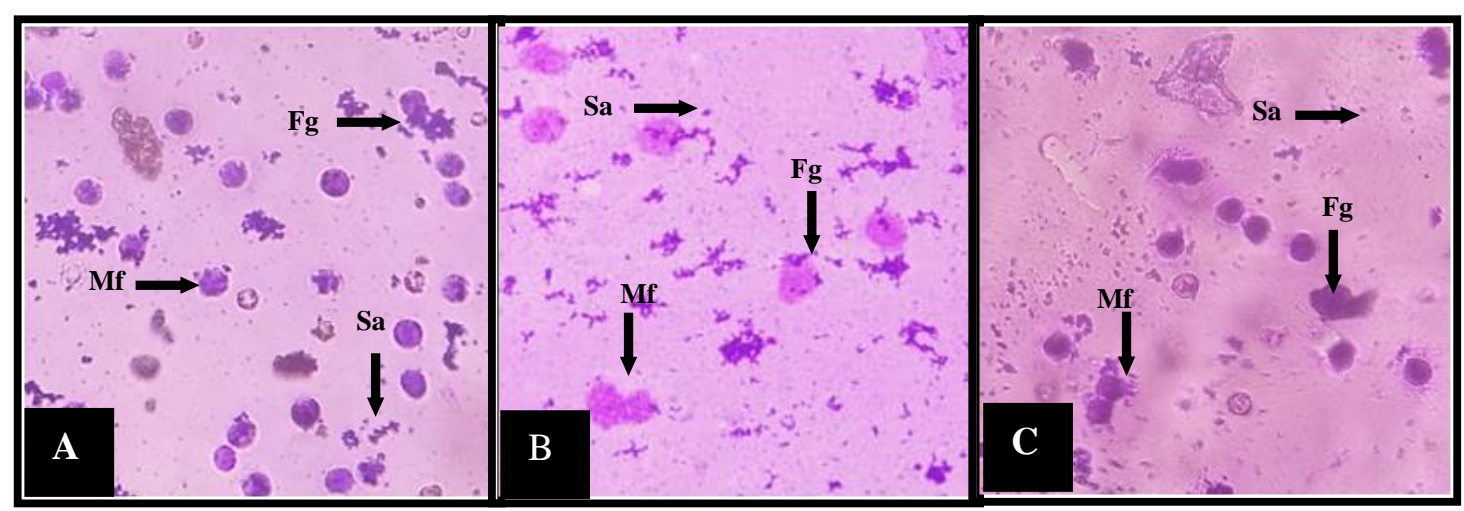

Gambar 3. Gambaran apusan cairan peritoneal ekstrak daun macang varietas limus. Keterangan A: Dosis 1, B: Dosis 2, C: Dosis 3. F: Fagositosis, M: makrofag, S: bakteri $S$. aureus 


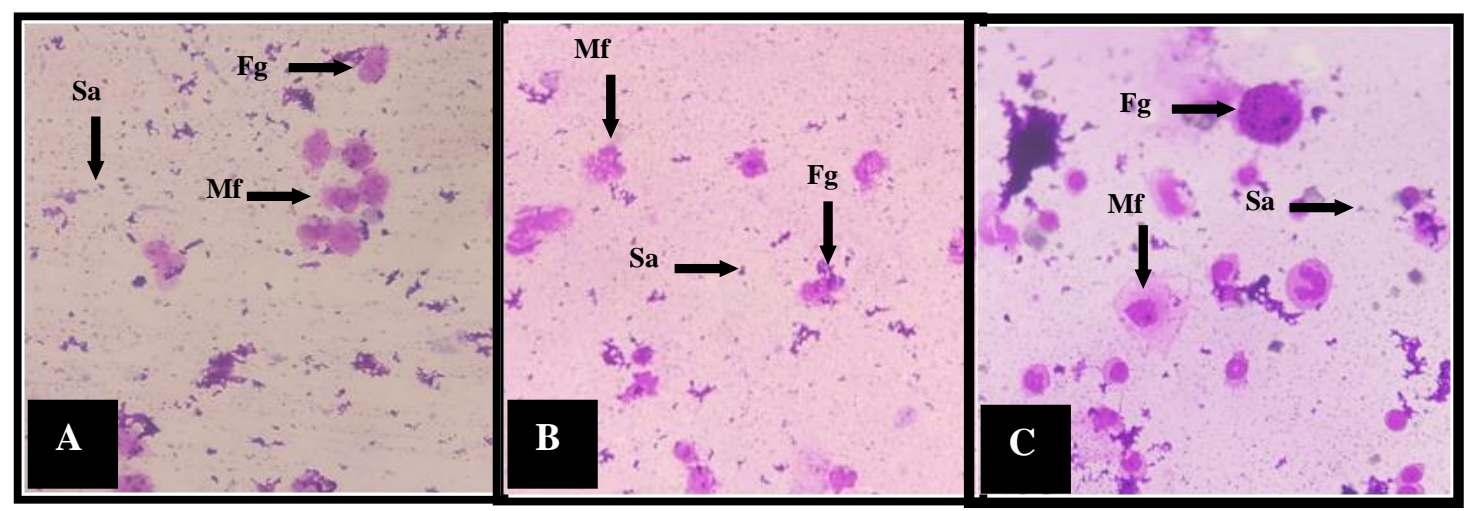

Gambar 4. Gambaran apusan cairan peritoneal ekstrak daun macang varietas manis. Keterangan A: Dosis 1, B: Dosis 2, Ce: Dosis 3. F: Fagositosis,

M: makrofag, S: bakteri $S$. aureus

Secara umum seluruh perlakuan pemberian ekstrak daun macang menunjukkan adanya aktivitas maupun kapasitas fagositosis. Sel makrofag disebut aktif apabila mengalami pembesaran sitoplasma dengan tepi yang jelas. Sebaliknya makrofag disebut inaktif jika sitoplasma kecil dan halus (Parawansah, et al., 2018). Hal ini terlihat pada pengamatan gambaran apusan cairan peritoneal keseluruhan perlakuan sesuai yang ditunjukkan pada gambar 1 sampai dengan gambar 4. Salah satu penanda terjadinya peningkatan imunitas yaitu meningkatnya aktivitas dan kapasitas fagositosis sel makrofag. Makrofag adalah sel fagositik yang berperan penting untuk menangkal serangan patogen melalui mekanisme fagositosis, baik oada respon imun bawaan maupun adaptif (Handayani, et al., 2018).

Persentase makrofag yang memfagositosis bakteri uji dihitung setiap 100 sel makrofag dinyatakan sebagai jumlah sel fagosit aktif (aktivitas).
Kemampuan fagositosis juga ditunjukkan oleh kapasitas sel makrofag yaitu banyaknya bakteri uji yang difagositosis oleh setiap sel makrofag aktif. Secara umum seluruh perlakuan pemberian ekstrak daun macang menunjukkan adanya aktivitas maupun kapasitas fagositosis. Kelompok kontrol positif menunjukkan perbedaan yang sangat kontras antara kontrol nol (aquades) dan kontrol negatif (CMC Na 1\%). Nilai aktivitas dan kapasitas sel makrofag oleh ekstrak daun macang dalam melakukan fagositosis dapat dianalisis dengan melakukan perhitungan sel makrofag aktif (aktivitas fagositosis) dan sel bakteri yang difagositosis oleh sel makrofag (kapasitas fagositosis). Perbedaan antar kelompok perlakuan terlihat melalui uji statistik ANOVA satu arah, dilanjutkan dengan uji DMRT. Data rerata perhitungan persentase aktivitas dan fagositosis dapat dilihat pada (Tabel 1) dan (Gambar 5). 
Vol. 11, No. 1 (2020) h. 111-141

Tabel 1. Rerata Aktivitas Fagositosis

\begin{tabular}{cllllll}
\hline Perlakuan & Dosis 1 & Dosis 2 & Dosis 3 & $\begin{array}{c}\mathrm{K} \\
+\end{array}$ & $\begin{array}{c}\mathrm{K} \\
0\end{array}$ & $\begin{array}{c}\mathrm{K} \\
-\end{array}$ \\
\hline Batu & $75^{\mathrm{b}}$ & $85^{\mathrm{cd}}$ & $89^{\text {cde }}$ & & & \\
Limus & $83^{\mathrm{c}}$ & $95^{\mathrm{ef}}$ & $93^{\mathrm{ef}}$ & & & \\
Manis & $91^{\mathrm{de}}$ & $94^{\mathrm{ef}}$ & $98^{\mathrm{f}}$ & & & \\
Stimuno & & & & $90^{\mathrm{de}}$ & & \\
Aquades & & & & & $66^{\mathrm{a}}$ & \\
CMC NA 1\% & & & & & & $62^{\mathrm{a}}$ \\
\hline
\end{tabular}

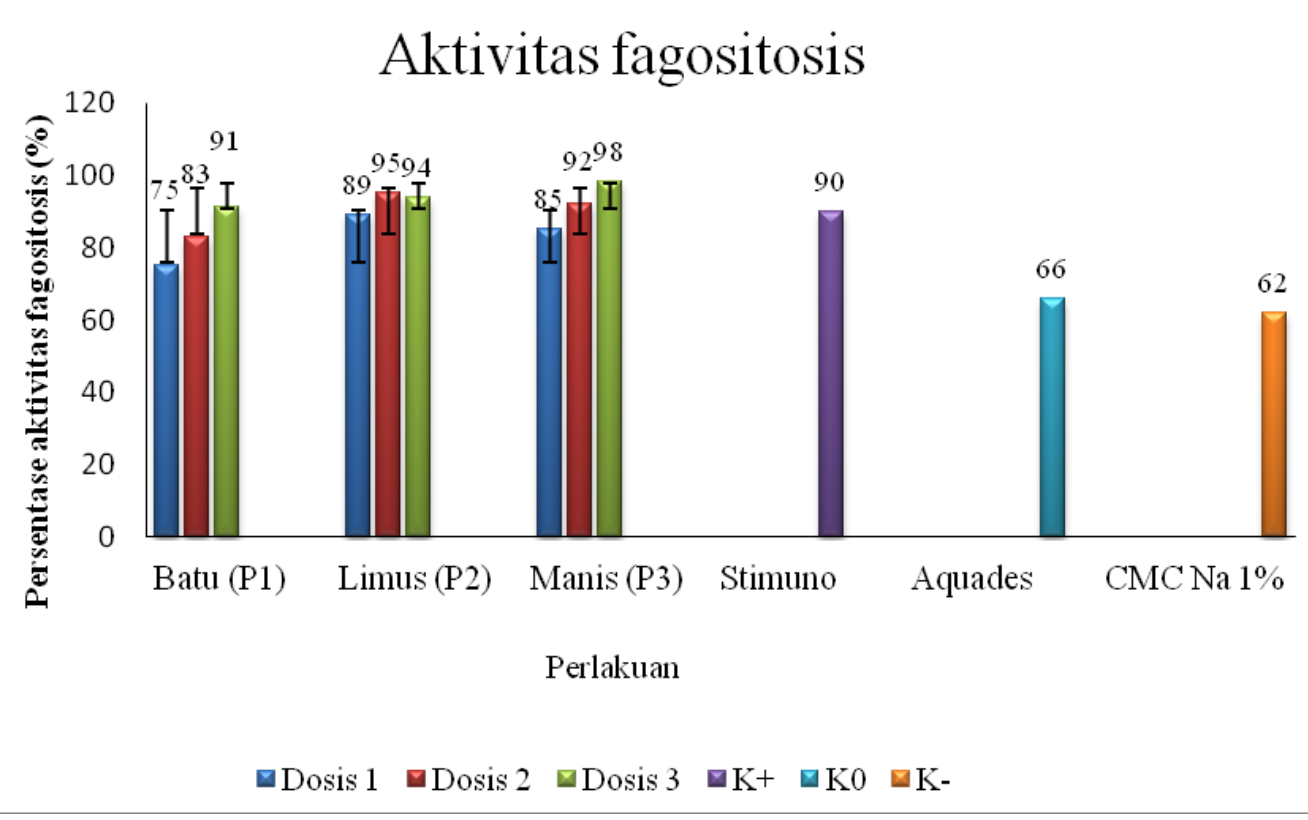

Gambar 5. Grafik persentase aktivitas fagositosis oleh ekstrak daun macang

Secara umum aktivitas fagositosis dari tiga varietas macang menunjukkan nilai yang lebih tinggi dibandingkan dengan perlakuan kontrol, terutama pada varietas manis menunjukkan nilai yang sama dengan kontrol positif oleh penggunaan dosis rendah (dosis 1).

Hasil uji ANOVA persentase aktivitas fagositosis sel makrofag dengan pemberian ekstrak daun macang diperoleh nilai $\mathrm{P}$ sebesar 0,000 . Nilai $\mathrm{P}<$ 0,05 artinya terdapat perbedaan yang nyata terhadap kemampuan aktivitas fagositosis sel makrofag tiap perlakuan.
Pemberian ekstrak varietas batu pada dosis 1 menunjukkan berbeda nyata dengan kelompok kontrol positif dengan persentase aktivitas sebesar 74,67 \pm $2,08 \%$. Hal ini menunjukkan bahwa dosis 1 belum efektif sebagai imunomodulator, sedangkan pada dosis sedang (dosis 2) menunjukkan adanya kemampuan imunomodulator dikarenakan persentase aktivitas fagositosis sama dengan kontrol positif (stimuno) $(85,00 \pm 7,81 \%)$. Penelitian serupa oleh Fitmawati, et al. (2018) menguji aktivitas imunomodulator dari ekstrak etanol Mangga Hutan pada cairan peritoneal 
mencit yang diinjeksikan bakteri $S$. aureus menggunakan 3 serial dosis menunjukkan

aktivitas fagositosis paling tinggi pada dosis 2 sebesar 84\%, lebih efektif dibandingkan dosis 1. Penelitian oleh Aldi, et al. (2014) menggunakan ekstrak meniran pada sel limfosit ayam broiler, menunjukkan bahwa indeks fagositosis (bobot limfa) terbesar yaitu dengan penggunaan dosis tinggi $(300 \mathrm{mg} / \mathrm{kg} \mathrm{BB})$ sebesar 0.2219 dan rata-rata indeks fagosit sel limfosist sebesar 21. Hal ini menunjukkan semakin tinggi dosis yang diberikan kemampuan aktivitas fagositosis juga semakin meningkat, begitu pula dengan penggunaan varietas batu, peningkatan dosis akan meningkatkan aktivitas fagositosis sel makrofag.

Persentase aktivitas fagositosis pada varietas limus dan manis dengan dosis rendah (dosis 1) memiliki nilai yang tidak berbeda nyata dengan kontrol positif dengan persentase masing-masing $83,33 \pm 2,89 \%$ dan $91,00 \pm 3,00 \%$. Rosnizar, et al. (2017) menguji aktivitas imunomodulator dari ekstrak daun flamboyan (Delonix regia) pada cairan peritoneal mencit terhadap peningkatan aktivitas dan kapasitas makrofag dengan menggunakan 3 serial dosis yaitu dosis 1 $(250 \mathrm{mg} / \mathrm{kg} \mathrm{bb})$, dosis $2(500 \mathrm{mg} / \mathrm{kg} \mathrm{bb})$ dan dosis $3(750 \mathrm{mg} / \mathrm{kg} \mathrm{bb})$.
Hasil menunjukkan bahwa dosis 3 memiliki aktivitas paling kuat yaitu 99,2\%. Namun, jumlah ini melampaui aktivitas fagositosis pada kontrol positif dengan persentase 95,2\%. Kemampuan aktivitas fagositosis yang mendekati kontrol positif yaitu dosis 2 sebesar $97,2 \%$.

Fitmawati, et al. (2017) melaporkan tentang aktivitas imunomodulator dari Ramuan Obat Pahit Lingga SP4 terhadap sel makrofag dengan 3 serial dosis yaitu dosis $1 \quad(0,011 \mathrm{~g} / 200 \mathrm{~g} \quad \mathrm{BB})$, dosis 2 $(0,023 \mathrm{~g} / 200 \mathrm{~g} \quad \mathrm{BB})$ dan dosis 3 $(0,034 \mathrm{~g} / 200 \mathrm{~g} \mathrm{BB})$. Hasil menunjukkan bahwa dosis 1 sebesar $94,00 \%$ tidak berbeda nyata dengan kontrol positif serta menunjukkan aktivitas fagositosis yang lebih baik, sehingga dosis rendah efekif digunakan sebagai imunomodulator.

Nilai kapasitas fagositosis ekstrak daun tiga varietas macang dapat diketahui dengan melakukan perhitungan jumlah sel bakteri yang difagositosis oleh sel makrofag. Berdasarkan aspek kapasitas fagositosis, varietas macang Batu, Limus dan Manis pada dosis rendah (dosis 1) menunjukkan nilai yang tidak berbeda nyata dengan kontrol positif. Perbedaan semua kelompok perlakuan dapat dilihat melalui uji ANOVA dan uji lanjut DMRT pada (Tabel 2) dan (Gambar 6) berikut.

Tabel 2. Rerata Kapasitas Fagositosis

\begin{tabular}{ccccccc}
\hline Perlakuan & Dosis & Dosis & Dosis & K & K & K \\
& 1 & 2 & 3 & + & 0 & - \\
\hline Batu & $330^{\mathrm{b}}$ & $462^{\text {cde }}$ & $370^{\text {de }}$ & & & \\
Limus & $532^{\text {bcde }}$ & $581^{\mathrm{e}}$ & $531^{\text {de }}$ & & & \\
Manis & $557^{\text {bc }}$ & $561^{\text {cde }}$ & $768^{\mathrm{f}}$ & & & \\
Stimuno & & & & $404^{\text {bcd }}$ & & \\
Aquades & & & & & $122^{\mathrm{a}}$ & \\
CMC NA 1\% & & & & & & $82^{\mathrm{a}}$ \\
\hline
\end{tabular}




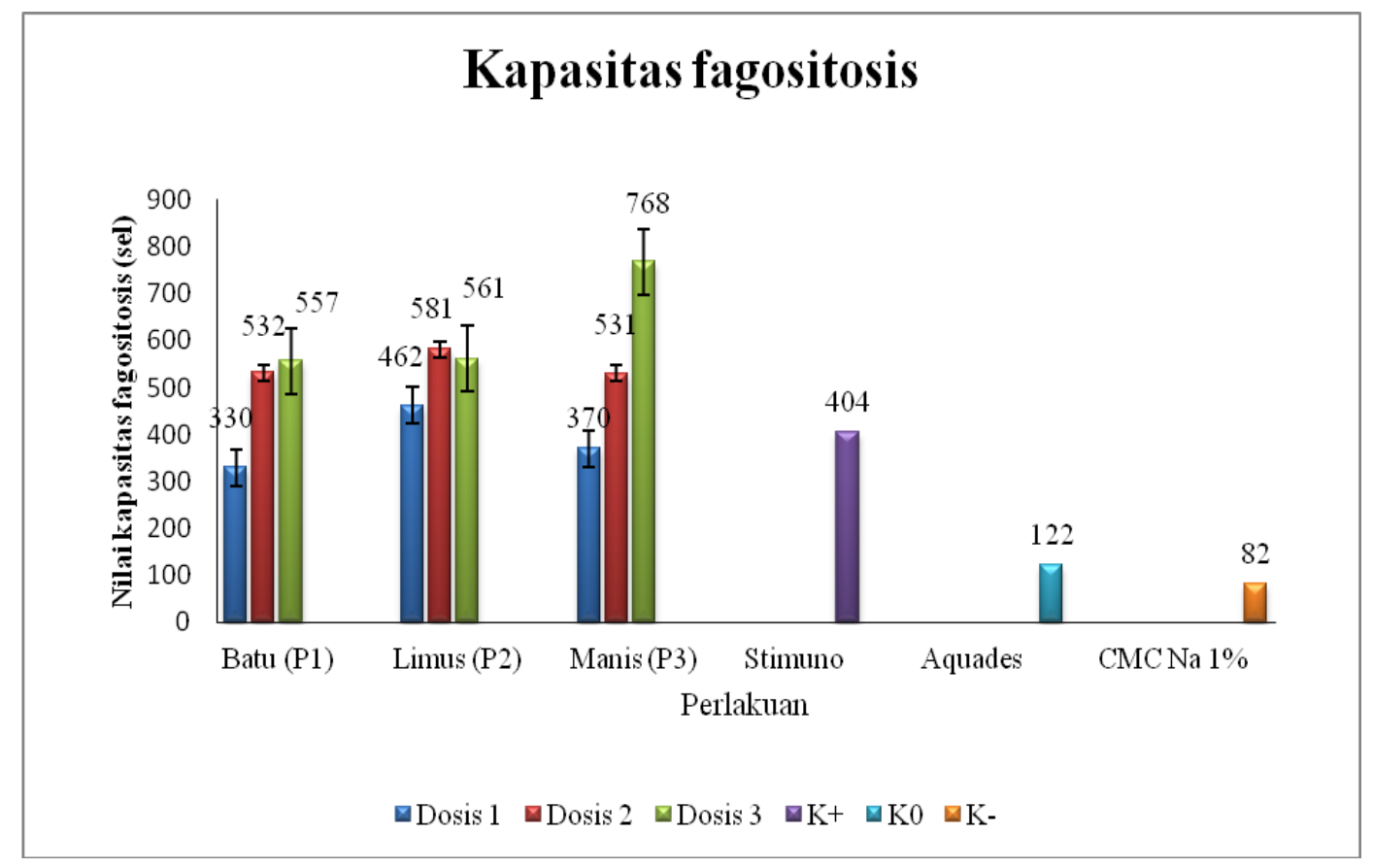

Gambar 6. Grafik nilai kapasitas fagositosis makrofag oleh ekstrak daun macang

Berdasarkan Tabel 2 rerata kapasitas fagositosis pada kontrol negatif menunjukkan nilai paling rendah yaitu $81,67 \pm 2,08$ dari 50 sel makrofag aktif dan berbeda nyata dengan seluruh perlakuan. Pemberian tiga serial dosis pada tiga varietas macang menunjukkan nilai yang tidak berbeda nyata dengan kontrol positif (stimuno). Kapasitas fagositosis pada dosis terendah sudah menunjukkan nilai yang sama dengan kontrol positif yaitu varietas Batu sebesar 330,00 $\pm 13,00 \%$, Limus 462,00 $\pm 29,00 \%$ dan Manis sebesar 369,00 \pm $44,06 \%$. Berdasarkan rerata nilai kapasitas fagositosis pada ekstrak tiga varietas macang, maka dosis terbaik yang dapat digunakan sebagai imunomodulator adalah dosis 1 (dosis rendah).

Penelitian Fitmawati, et al. (2016) tentang uji efektivitas imunomodulator dari infusa ramuan obat pahit linau terhadap kapasitas fagositosis cairan peritoneal tikus putih dengan 3 serial dosis, menunjukkan bahwa konsentrasi optimal untuk meningkatkan kapasitas fagositosis adalah pada dosis terkecil yaitu $0,009 \mathrm{~g} / 200 \mathrm{~g} \mathrm{BB}$ dengan nilai kapasitas fagositosis 169 dari 50 sel makrofag aktif. Sedangkan untuk dosis $0,019 \mathrm{~g} / 200 \mathrm{~g}$ BB dan 0,028 g/200g BB menurunkan kemampuan kapasitas fagositosis dengan nilai masing-masing 141 dan 112 dari 50 sel makrofag aktif. Hal ini mungkin disebabkan penggunaan dosis tinggi ekstrak ramuan ini memiliki sifat toksik lebih tinggi daripada sifat imunostimulannya sehingga terjadi efek penurunan imuostimulan.

Imunostimulan bertindak untuk mengembalikan/memperkuat sistem kekebalan tubuh yang fungsinya terganggu atau lemah dan menekan fungsi yang berlebihan (Patil, et al., 2012). Dalam studi ini dilakukan pengujian imunomodulator melalui aspek aktivitas dan kapasitas fagositosis oleh sel makrofag. Suatu bahan atau obat memiliki kemampuan imunomodulator 
jika terjadi peningkatan imunitas yaitu meningkatnya aktivitas dan kapasitas fagositosis sel makrofag.

Hasil yang diperoleh menunjukkan bahwa pemberian dosis rendah sudah menunjukkan kemampuan imunomodulator pada masing-masing varietas. Kemampuan ini dikarenakan adanya kandungan fitokimia yang terdapat pada daun macang. Menurut Bouayed \& Bohn (2010), senyawa aktif yang memiliki kemampuan antioksidan pada suatu ekstrak dalam dosis kecil dapat digunakan sebagai obat dan apabila berlebihan mengakibatkan terganggunya fisiologi sel, sehingga dapat bersifat toksik.

Penggunaan pelarut yang digunakan dalam proses ekstraksi juga mempengaruhi senyawa yang telarut. Pelarut polar mampu menarik senyawa yang memiliki kelarutan yang cukup dan kemampuan absorbsi yang optimal menembus membran sel (Arifah, et al., 2014). Berdasarkan penelitian Fitmawati, et al. (2017) ekstrak ramuan obat pahit dengan pelarut metanol memiliki aktivitas antioksidan sangat kuat dibandingkan ekstrak ramuan obat pahit yang menggunakan pelarut air. Hal ini dikarenakan pelarut metanol mampu melarutkan senyawa bioaktif yang terdapat dalam ramuan obat pahit dibandingkan pelarut air aquades.

Mangiferin adalah senyawa bersifat farmakologis yang terdapat pada genus mangifera (mangga) (Matkowski, et al., 2013). Mangiferin dalam daun Mangifera foetida merupakan flavonoid bersifat antioksidan untuk menangkal radikal bebas, serta sifat aktivitas farmakologi dalam beberapa proses pathogenesis, salah satunya sebagai agen imunomodulator (Masibo \& He, 2008). Penelitian oleh Ranjedran, et al. (2013) menunjukkan bahwa mangiferin dapat meningkatkan jumlah leukosit, limfosit, neutrofil, IgG dan IgM ketika terinduksi senyawa karsinogenesis tetapi tidak pada keadaan normal.

Flavonoid memiliki antioksidan yang kuat, dan terbukti sebagai antiinflamasi, antialergi dan antikanker (Torres-Leon, et al., 2016). Berdasarkan kandungan senyawa tersebut maka macang memiliki efek yang kuat sebagai imunomodulator. Sehingga diharapkan dapat memberikan informasi obat imunomodulator terbaru terhadap penyakit infeksi dan dikembangkan menjadi bahan baku obat herbal (fitofarmaka).

\section{SIMPULAN DAN SARAN}

Berdasarkan hasil penelitian yang telah dilakukan dengan menggunakan serial dosis berbeda dapat disimpulkan bahwa pada tiga varietas macang (Batu, Limus dan Manis) terbukti efektif sebagai imunomodulator. Dosis $1(1 \mathrm{ppm}=0,001$ $\mathrm{mg} / \mathrm{g}$ ) pada macang varietas limus dan manis sudah menunjukkan kemampuan imunomodulator, sehingga tidak perlu peningkatan dosis dengan masing-masing presentase aktivitas fagositosis $83,33 \pm 2,89 \%$ dan $91,00 \pm 3,00 \%$. Sedangkan pada varietas batu dosis $2(10$ $\mathrm{ppm}=0,01 \mathrm{mg} / \mathrm{g}$ ) lebih efektif untuk digunakan. Adanya perbedaan persentase kemampuan aktivitas fagositosis tiap perlakuan pemberian ekstrak daun macang dapat disebabkan oleh perbedaan dosis maupun komposisi kandungan kimia yang terdapat dalam masingmasing varietas macang. Hasilnya diharapkan memberikan informasi obat imunomodulator terbaru terhadap penyakit infeksi dan diharapkan dapat dikembangkan menjadi bahan baku fitofarmaka. Perlu dilakukan penelitian lanjutan untuk menguji ekstrak daun macang dengan variasi dosis serta pelarut 
yang berbeda dan perlu dilakukan uji toksisitas, sehingga penggunaannya lebih aman dan efektif bagi manusia.

\section{DAFTAR PUSTAKA}

Ahmad, R. Munim, A. Elya, B. (2012). Study of Antioxidant Activity With Reduction of Free Radical and Xanthin Oxidase Inhibitor of The Extract of Ruellia tuberosa L. Leaf. International Research Journal of Pharmacy

Aldi Y, Rasyadi Y \& Handayani D. (2014). Aktivitas Imunomodulator dari Ekstrak Etanol Meniran (Phyllanthus niruri Linn.) terhadap Ayam Broiler. Jurnal Sains Farmasi dan Klinis, 1(1):20-26.

Arifah, A. N. Nurkhasanah. (2014). Efek Fraksi Etil Asetat Ekstrak Etanol Akar Pasak Bumi (Eurycoma longifolia, Jack) Terhadap Aktivitas Fagositosis Makrofag Secara In Vitro. Journal of Pharmaciana 4(1):14.

Bouayed, J \& Bohn, T. (2010). Exogenous Antioxidants DoubleEdged Swords in Cellule Redox State: Helath Beneficial Effects at Physiologic Doses Versus Deletrerious Effects at High Doses. Oxid Med Cell Longev. 3(4):228237.

Fitmawati, Isnaini, Roza RM \& Sofiyanti N. (2016). Biosprospek Ramuan Panjang Umur Warisan Leluhur Masyarakat Melayu Lingga kepulauan Riau Sebagai Imunomodulator dan Antioksidan. Laporan Penelitian Lanjutan Riset
Tanaman Obat dan Jamu. Universitas Riau, Pekanbaru.

Fitmawati, Roza R. M., Sofiyanti N., Isnaini, Fitri F. L., Paramita D., Dewi A. P. K. (2017). Immunomodulatory effectiveness of Aqueous Obat Pahit Extract of Lingga Malay Ethnic on White Rats (Rattus novergicus). Biosaintifika: Journal of Biology dan Biology Education, 9(3):430-436.

Fitmawati, Juliantari E. Saputra A, sinaga P, Roza R. M, \& Isda, M. N. (2018). The Potential of Wild Mango Leaves from Sumatera as the Immunostimulant Agent. Biosantifika: Journal of Biology \& Biology Education, 10(3), 671-677.

Grace, U. Steve, O. Teddy, E. Shakirat, B. (2013). Imunostimulatory And Biochemical Effects Of Ethanolic Extract Of Mangifera indica Stem Bark on Dexamethasone-Induced Immunosupressed Male Rats. International of Pharmacy and Pharmaceutical Science. 5(2),569572.

Handayani, N. Wahyuono, S. Hertiani, T, Murwanti, R. (2018). Uji Aktivitas Fagositosis Makrofag Ekstrak Etanol Daun Suji (Dracaena angustifolia (Medik Roxb) Secara In vitro. Pharmacy Medical Journal. 1(1): 26-32.

Limyati A. D \& Y. S. Essay. (2003). Uji Antioksidan, Antiradikal Bebas dan Penentuan EC 50 Ekstrak Diklorometana Serta Ekstrak Metanol Herba Sambiloto (Andrographis paniculata Burn. F. 
Ness.). Jurnal Obat Bahan Alam. Vol.1 No 2.

Matkowski A., Kus P., Goralska E., \& Wozniak D. (2013). Mangiferin -a bioactive xanthonoid, not only from mango and not just antioxidant. Mini Rev Med Chem.13(3):439-55.

Masibo M, and He Q. (2008). Major mango polyphenols and their potential significance to human health. Compr Rev Food Sci Food Saf. 7(4):309-19.

Parawansah, T. Nurtamin, S. A Mulyawati, Nuralifah, W. O. A Misnaeni. (2018). Immunomodulatory Effect of Momorcadia charantia L. Fruit Ethanol Exract on Phagocityc Activity and Capacity of Mice Peritoneal Macrophages. Indones Biomed J. 10(2):144-147.

Patil, U. S. Jaydeokar, A. V. Dandawane, D. D. (2012). Immunomodulators: A Pharmacological Review: International Journal of Pharmacy and Pharmaceutical Science. 4(1):30-36.

Purwaningsih, Erie H, Endang, Amalia, Pustika, Krisnamurti, Desak G. B. (2011). The Chelating Effect of Mangifera foetida $L$. water Extract On serum Thalassemic-Patients, $J$. Indonesian Medical Assoc 61(8):321-325.

Rahim A. M, Nyoman Su, Luh M. S. (2017). Efek Imunostimulator Ekstrak Daun Kasturi (Mangifera Casturi) Pada Mencit. Indonesia Medicus Veterinus 6(1):10-19.
Ranjedran P, Jayakumar T, \& Sathisekaran D. (2013) Immunomodulatory effect of mangiferin in experimental animals with benzo(a)pyrene-induced lung carcinoge-nesis. Int J Biomed Sci. 9(2);68-74

Rosnizar, S. Maulida, K. Eriani \& Suwarno. (2017). Potensi ekstrak daun flamboyan [Delonix regia (Boj. Ex Hook.) Raf.] terhadap peningkatan aktivitas dan kapasitas makrofag. BIOLEUSER 1(3):104115.

Savant, C. Kulkarini, A. R. Mannasaheb, B. A, Gajare, R. (2014). Immunostimulant phytoconstituents from Mangifera indica L. bark oil. The Journal of Phytopharmacology. 3(2):139-148

Siswanty, P. W, Muhammad, A. W., \& Harlia. (2017). Aktivitas Toksisitas Antioksidan Dan Antiinflamasi Secara In Vitro Dari Ekstrak Metanol Daun Mangga Bacang (Mangifera foetida L.). JKK. 6(1):42-49.

Torres-Leon, C., Rojas, R., ContrerasEsquivel, J. C., Serna-Cock, L., Belmares-Cerda, R. E., Anguilar, C. M. (2016). Mango seed: Functional and Nutritional Properties. Trends in Food Science dan Technology 55: 109-117.

Wei, Z. Q. Deng, J. G, Yan, L. (2011). Pharmacological Effects of Mangiferin. Chinese Herbal Medicines. 3(4): 266-271.

Yulinery \& Nurhidayat. (2012). Penggunaan Ekstrak Fermentasi 
Jurnal Pendidikan Matematika dan IPA

Vol. 11, No. 1 (2020) h. 111-141

Beras dari Beberapa Jenis

Peritoneum Mencit sebagai Monoascus pupureus untuk Imunomodulator. Berita Biologi Aktivitas In Vitro Fagositosis Sel 11(2):283-273.

Makrofag dan Polimorfonuklear 